\title{
DIVISION INITIALE DE SPOROZOITES D'UNE ISOSPORA DE MOINEAU EN CULTURE CELLULAIRE
}

\author{
P. MILLET, J. BAXTER et I. LANDAU*
}

\section{Sporozoites primary division in the sparrow Isospora in cell culture.}

SUMMARY. The study of the sparrow Isospora in cell culture has demonstrated that during the extra-intestine life cycle, sporozoites undergo a primary division, resulting into two similar elements, whereas, in plain intra-intestinal cycle, the sporozoite is straightforwardly transformed into the first generation schizont.

Box (1977) a décrit le cycle biologique expérimental de 2 espèces d'Isospora chez le canari (Serimus canarius). I. canaria évolue entièrement dans l'épithélium intestinal, alors que $I$. serini se développe d'abord dans le système réticulo-endothélial, puis dans l'intestin.

Il a été montré par ailleurs (Grulet et al., 1982, et travail en préparation) que, chez le moineau domestique (Passer domesticus), qui est parasité par de nombreuses espèces d'Isospora, ces 2 types de cycle coexistent.

Dans le but d'étudier la succession des générations schizogoniques asexuées des parasites du moineau, nous avons infesté avec des sporozoïtes des cultures primaires de cellules hépatiques.

Les sporozoïtes ont été obtenus par excystation (selon la technique de Jackson, 1964) d'oocystes récoltés dans les fèces de moineaux capturés en Normandie.

Les cellules hépatiques ont été prépareés par perfusion enzymatique de foie de canari avec de la collagénase : il s'agit d'hépatocytes et de fibroblastes.

Les sporozoïtes ont été déposés sur les cultures $72 \mathrm{~h}$ après la perfusion.

Nous avons observé en culture les deux types d'évolution schizogonique décrits par Box, aussi bien dans les hépatocytes que dans les fibroblastes :

a) espèces à cycle exclusivement intestinal : 3 schizogonies successives en 5 jours, avec mérozoïtes de grande taille,

b) espèces à cycle mixte réticulo-endothélial et intestinal : plusieurs générations schizogoniques en 10 jours, avec mérozoïtes de petite taille. (Ce nombre de générations n'est pas encore exactement déterminé : il est de 3, 4 ou 5).

* Laboratoire de Zoologie-Vers, associé au CNRS, Muséum National d'Histoire Naturelle, 61 rue Buffon, F 75231 Paris Cedex 05.

Accepté le 17 mai 1984 . 
La différenciation des deux cycles se fait dès l'entrée du sporozoïte dans la cellule.

- Cycle intestinal strict : le sporozoïte se transforme directement en schizonte de $1^{\text {re }}$ génération, qui mûrit en moins de 18 heures.

- Cycle mixte : le sporozoïte, entre 2 et 18 heures, effectue une division initiale en deux : dès sa pénétration dans la cellule, les 2 cristalloïdes se placent à chaque extrémité du corps : le noyau, au centre, se divise, pendant que le sporozoïte subit une section transversale en son milieu. Il en résulte 2 éléments semblables, pourvus chacun d'un cristalloïde. En outre, un corps résiduel, paraissant correspondre à de la chromatine, est rejeté à l'intérieur de la vacuole parasitophore.

\section{BIBLIOGRAPHIE}

Box E. D. : Life cycles of two Isospora species in the canary, Serinus canarius L. J. Protozool., $1977,24,57-67$.

Grulet O., Landau I., Baccam D. : Les Isospora du Moineau domestique : Multiplicité des espèces. Ann. Parasitol. Hum. Comp., 1982, 57, 209-235.

JACKson A. R. B. : The isolation of viable Coccidial sporozoites. Parasitology, 1964, 54, 87-93. 